\title{
TRAILER HEAT ZONES AND THEIR RELATION TO HEAT STRESS IN PIG TRANSPORT
}

\author{
Nítalo A. F. Machado ${ }^{1 * 2}$, José A. D. Barbosa-Filho², Geraldo L. B. Ramalho3, \\ Héliton Pandorfi ${ }^{4}$, Iran J. O. Da Silva ${ }^{5}$
}

\begin{abstract}
${ }^{1 *}$ Corresponding author. Center for Agrarian and Environmental Sciences - UFMA/ Chapadinha - MA, Brazil.
E-mail: nitalo.farias@ufma.br | ORCID ID: https://orcid.org/0000-0002-4967-2620
\end{abstract}

\section{KEYWORDS \\ bioclimatology, animal welfare, pre- slaughter, precision animal production.}

\begin{abstract}
This study evaluates the dynamics of heat zones in the load and its relationship with the stress of pigs during transport. Four journeys of $170 \mathrm{~km}$ were monitored, recording the physiological variables of 192 animals (48 per journey), namely rectal temperature (RT), body temperature (BT), respiratory rate (RR), blood lactate concentrations and salivary cortisol. Heat zones and ventilation patterns were characterized by the spatial variability of the enthalpy and the Computational Fluid Dynamics of the load. The formation of a thermal core was observed in the frontal region of the load, which extended through the lower (LD) and upper (UD) decks. Pigs transported in the LD had higher means of RR (UD $=89$ and $\mathrm{LD}=94$ breaths $/ \mathrm{min}$ ), and salivary cortisol $(\mathrm{UD}=33.84$ and $\mathrm{LD}=34.92$ $\mathrm{ng} / \mathrm{mL}$ ). The pigs transported in the UD presented the highest mean BT (UD $=38.9$ and $\mathrm{LD}=38.1{ }^{\circ} \mathrm{C}$ ) and lactate (UD $=61.63$ and $\mathrm{LD}=58.26 \mathrm{mg} / \mathrm{dL}$ ). Pigs transported in the LD of the load were more susceptible to thermal stress, while pigs transported in the UD showed greater physical stress and muscle exhaustion.
\end{abstract}

\section{INTRODUCTION}

The pre-slaughter management, formed by the stages of loading, transporting, unloading and waiting for the pigs at the slaughterhouse, when associated with inappropriate practices, can compromise the well-being, survival and quality of the swine meat (Faucitano, 2018). Losses are estimated to reach US $\$ 160,000 /$ year per slaughterhouse in Brazil, mainly in the transport stage (Dos Reis et al., 2015).

During transport, pigs are subjected to many factors that can cause stress, such as mixing batches, deprivation of food and water, changes in the environment, vibrations and loud noise (Mota-Rojas et al., 2014). However, the thermal environment of the cargo is considered to be one of the main factors responsible for the increase in the rate of death of animals on arrival (DOA) (Averós et al., 2010), especially due to the fact that pigs have limited energy dissipation through evaporation, due to its low sweating efficiency (Bligh, 1985), making them more susceptible to losses during transport (Rioja-Lang et al., 2019).
Understanding the effects of meteorological elements that act as stressors and increase the challenge imposed on pigs during transportation, in a tropical climate, is essential to elucidate the potential deleterious effects of heat stress and losses that may occur during this process (Machado et al., 2021a)

In addition, studies indicate that the pigs' boarding in certain behaviors of the bodywork associated with the impacts caused by the vibration of the load along the trip can cause a scenario of greater susceptibility to physical stress and muscular exhaustion in the pigs transported in certain regions of the trailer (Peeters et al., 2008; Conte et al., 2015).

Studies have shown substantial variations in relative humidity throughout the truck compartments during swine transport, with considerable air temperature heterogeneity, which exceeds the outside temperature by up to $8^{\circ} \mathrm{C}$ (Correa et al., 2013; Fox et al., 2014; Pereira et al., 2018). A great heterogeneity in the enthalpy of the load can provide zones of high heat (thermal core), associated with the regions with

${ }^{1}$ Center for Agrarian and Environmental Sciences - UFMA/ Chapadinha - MA, Brazil.

${ }^{2}$ NEAMBE - Department of Agricultural Engineering - DENA/ UFC/ Fortaleza - CE, Brazil.

${ }^{3}$ Department of Industry - IFCE/ Fortaleza - CE, Brazil.

${ }^{4}$ Department of Rural Technology - UFRPE/ Recife - PE, Brazil.

${ }^{5}$ NUPEA - Department of Biosystems Engineering - ESALQ/ USP/ Piracicaba - SP, Brazil.

Area Editor: Danilo Florentino Pereira

Received in: $12-8-2020$

Accepted in: 6-19-2021 
greater losses, about everything by animal deaths (Pinheiro et al., 2021).

Poultry farming has a similar problem related to the flow of air and energy and the effect of thermal stress on transport vehicles. Studies have shown that the distribution of dead birds along the load during transport is not random; the points with the highest DOA rate correspond to the thermal zones with the highest energy content, known as thermal cores (Mitchell \& Kettlewell 1998; Kettlewell et al., 1993; Kettlewell et al., 2001; Barbosa-Filho et al., 2009; Pinheiro et al., 2021).

In this context, the objective of this study is to evaluate the dynamics of the heat zones of the load and its relationship with the stress of pigs during the transport operation

\section{MATERIAL AND METHODS}

\section{Study location and period}

Four journeys were monitored in the afternoon shift (14h: $30 \mathrm{~min}$ to $17 \mathrm{~h}: 40 \mathrm{~min}$ ) with a $170 \mathrm{~km}$ route in the period from 16 to 28 February 2020 , between a farm located in Maracanaú - CE, Brazil (3 ${ }^{\circ} 54 ' 46.4$ " S $38^{\circ} 39 ' 19.2$ "W and $43 \mathrm{~m}$ altitude) and the slaughterhouse in the city of Morada Nova - CE, Brazil (5 06 '24" S $38^{\circ} 22^{\prime} 21$ "W and $52 \mathrm{~m}$ altitude).

According to data provided by stations 82397 Fortaleza (349'12 "S 38 $32^{\prime} 24^{\prime \prime} \mathrm{W}$ and $29.89 \mathrm{~m}$ high) and 82588 - Morada Nova (5²'24 "S 38 21'36" W and $45.02 \mathrm{~m}$ high) of the National Institute of Meteorology of Brazil (INMET), the variation of solar radiation during the transport period was 412 to $520 \mathrm{~kJ} / \mathrm{m}^{2}$, the ambient temperature was 26.8 to $31.0{ }^{\circ} \mathrm{C}$ and the relative humidity from 66 to $72 \%$.

\section{Animals and Treatments}

A total of 384 crossbred pigs (Large White $\mathrm{x}$ Landrace $\mathrm{x}$ Duroc) around 165 days old were transported. A subsample of 192 animals (48 per journey), with an average body weight of $124.0 \pm 2.8 \mathrm{~kg}$, were selected by random sampling blocked by sex (female) and location within the trailer ( 4 animals per compartment) identified with markings of ink in the dorsal and auricular region in the farm pen $80 \pm 15$ min before loading, to receive the protocol for recording physiological variables.

The design adopted was in randomized blocks, with the blocking factor being the travel day. The variation factors investigated were the compartments of trailer. All procedures were approved and performed following the guidelines of the Ethics Committee on the Use of Animals of the Agricultural Sciences Center of the Federal University of Ceará (Process number 9871250719).

\section{Infrastructure and logistics}

The journeys were conducted on paved roads, with a pig load density of $290 \mathrm{~kg} / \mathrm{m}^{2}$. The transport was carried out in a Ford $®$ truck model cargo 1519, with model Triel® - HT with two fixed floors containing 6 compartments, totaling 12 compartments and a load capacity of 13 tons. The feeding was suspended $120 \pm 20$ min before loading started.

The animals were guided during the embarkation with the aid of flags. Pre-molded loading ramps with a $30^{\circ}$ inclination and a metallic ramp $\left(\sim 3 \mathrm{~m}\right.$, inclination $58^{\circ}$ for loading on the upper deck of the load) were used both for loading and unloading pigs.

During loading, the pig load was wetted by an employee using a hose. This is standard practice in tropical regions and aims to reduce the impacts of thermal stress (Pinheiro et al., 2020). The "wetting of the load" is carried out randomly along the trailer. In this study, based on flow and operating time, we estimated that an average of 2,710 \pm 258 liters/load of water were used $( \pm \mathrm{SE})$.

\section{Load Environmental Monitoring}

The temperature $\left(\mathrm{TA},{ }^{\circ} \mathrm{C}\right)$ and the relative humidity of the air $(\mathrm{RH}, \%)$ inside the load were measured every 10 min, using twelve dataloggers (Onset, U23-001 HOBO Pro v2), with accuracy of $\mathrm{TA} \pm 0.2^{\circ} \mathrm{C}$ and $\mathrm{RH} \pm 2.5 \%$, installed in the geometric center of each compartment of the truck, at the height of the animals. The thermal characterization of the load was performed based on the specific enthalpy $(\mathrm{H}$, $\mathrm{kJ} / \mathrm{kg}$ of dry air), as proposed by (Rodrigues et al., 2011).

$\mathrm{H}=1.006 . \mathrm{TA}+\frac{\mathrm{RH}}{\mathrm{Pb}} \cdot 10^{7.5 \mathrm{TA}(237.3+\mathrm{TA})^{-1}} .(71.28+0.052 \mathrm{TA})$

Where:

TA is the air temperature in ${ }^{\circ} \mathrm{C}$;

$\mathrm{RH}$ is the relative humidity in $\%$, and

$\mathrm{Pb}$ is the local barometric pressure in $\mathrm{mmHg}$.

\section{Load Ventilation Simulation}

A full-scale virtual model of the truck and trailer was developed using the Solid Edge ST10 software (Figure 1). The software used for the study of computational fluid dynamics (CFD) was SolidWorks Flow Simulation, ver.2020, employing an adaptive mesh generation in the computational mesh adaptation process. 


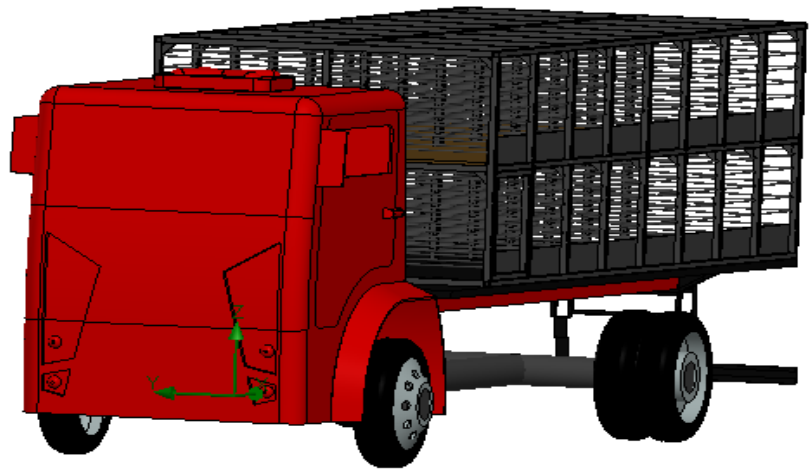

FIGURE 1. Virtual model of the vehicle with the trailer used to transport pigs.

In this study, the software's automatic mesh generator was used, using hexahedral cells structured in most of the domain, except around the truck, where tetrahedral cells were used with refinement in the layers along the truck's surface.

The number of cells in the mesh was 10,339, resulting in a maximum orthogonal quality of $79.60 \%$. The boundary conditions were designed to simulate the actual flow conditions during transport (Table 1). These conditions were established with the actual data, recorded in the monitored transport journeys.

TABLE 1. Boundary conditions.

\begin{tabular}{lc}
\hline Variables & Reference values adopted \\
\hline Prescribed speed & $18.00 \mathrm{~m} / \mathrm{s}(64.8 \mathrm{~km} / \mathrm{h})$ \\
Air temperature & $27.50^{\circ} \mathrm{C}$ \\
Relative humidity & $68.00 \%$ \\
Radiation & $460.00 \mathrm{~kJ} / \mathrm{m}^{2}$ \\
Atmospheric pressure & $760.00 \mathrm{~mm} \mathrm{Hg}$ \\
\hline
\end{tabular}

\section{Characterization of heat zones}

The exploration of the spatial variability of enthalpy along the load was carried out using geostatistics techniques, with the construction of $2 \mathrm{D}$ thematic maps in Surfer® V.10 (Golden Software, Inc.) and 3D using the SGeMS® software (Remy et al., 2009). The points mesh used consisted of 36 points, 12 points generated from the dataloggers during transport and 24 points exported after the CFD simulation.

The SGeMS ${ }^{\circledR}$ is a free program specialized in the visualization of volumetric data 3D, voxels (cubes) (Remy et al., 2009; Gasparin et al., 2017). The interpolation method in the construction of thematic maps was ordinary kriging (2) and the structure and spatial dependence established by the semivariogram (3).

$\overline{\mathrm{Z}}\left(\mathrm{S}_{\mathrm{o}}\right)=\sum_{\mathrm{i}=1}^{\mathrm{n}} \lambda_{\mathrm{i}} * \mathrm{Z}\left(\mathrm{S}_{\mathrm{i}}\right)$

Where:

$\mathrm{Z}\left(\mathrm{S}_{\mathrm{o}}\right)$ is the value interpolated at position $\mathrm{S}_{\mathrm{o}}$;

$\lambda_{\mathrm{i}}$ is the weight attributed to the $\mathrm{i}$-th value sampled in position $\mathrm{S}_{\mathrm{i}}$;

$\mathrm{Z}\left(\mathrm{S}_{\mathrm{i}}\right)$ is the sampled assigned value; $\mathrm{n}$ is the number neighboring locations used interpolate the point,

and the sun of the weights $\lambda_{\mathrm{i}}$ must be equal to 1 and $0 \leq \lambda_{\mathrm{i}} \geq 1$.

$\bar{\gamma}(\mathrm{h})=\frac{1}{2 \mathrm{n}_{(\mathrm{h})}} \sum_{\mathrm{i}=1}^{\mathrm{N}(\mathrm{k})}\left[\mathrm{Z}\left(\mathrm{x}_{\mathrm{i}}\right)-\mathrm{Z}\left(\mathrm{S}_{\mathrm{i}}+\mathrm{h}\right)\right]^{2}$

Where:

$\bar{\gamma}(\mathrm{h})$ is the value interpolated at position;

$h$ is the separation distance between the measurements;

$\mathrm{N}_{(\mathrm{k})}$ is the number of experimental pairs of measured data from $\mathrm{Z}(\mathrm{xi})$ and $\mathrm{Z}(\mathrm{si}+\mathrm{h})$;

$\mathrm{Z}$ (si) is the value of the variable for position si not estimated (true) considered as a random variable, depending on the position of the sampling $\mathrm{x}$,

$\mathrm{Z}(\mathrm{si}+\mathrm{h})$ is the value of the same variable in the $\mathrm{Si}+$ $\mathrm{h}$ position in any direction.

The enthalpy values were organized in Excel® using the GSLIB (Geostatistics Software Library) standard. The GSLIB file was inserted into SGeMS $®$ using the option "Load Objetict" and "point sed". The semivariograms were built in the "Algorithms-Estimation" section and the "kriging" option was selected.

The interpolation process is carried out by complementing points that define the image from known points, that is, similar to the computational processes of two-dimensional maps, however in SGeMS $®$ it occurs in a $3 \mathrm{D}$ perspective by building the mesh in three dimensions, called voxels (cubes). The three-dimensional map of the enthalpy was generated using the "Run Algorithm" option, and the visualization in the "Volume explorer" section.

\section{Physiological parameters}

The indicators used in the swine physiological data recording protocol were rectal temperature $\left(\mathrm{RT},{ }^{\circ} \mathrm{C}\right)$, body temperature $\left(\mathrm{BT},{ }^{\circ} \mathrm{C}\right)$, respiratory rate $(\mathrm{RF}$, breaths $/ \mathrm{min})$ and lactate concentrations blood $(\mathrm{mg} / \mathrm{dL})$ and salivary cortisol $(\mathrm{ng} / \mathrm{mL})$. In this study, the physiological parameters were measured $45 \pm 12$ min before loading at origin site and $25 \pm$ 15 min after unloading the animals at destination in the slaughterhouse's waiting pen.

The RR and BT were recorded before the pigs were contained, without physical interference. Then, the pigs 
were lightly and briefly contained (maximum 2 minutes) in the dorsal duct to record RT, salivary cortisol and blood lactate concentration. All samples were taken from each animal in $3 \pm 1 \mathrm{~min}$.

Rectal temperature was measured using skewer thermometer with $\pm 0.5^{\circ} \mathrm{C}$ accuracy $\left(-10\right.$ to $100^{\circ} \mathrm{C}$, AK05, AKSO), inserted directly into the animal's rectum. Respiratory rate was measured by two trained specialists observing the movement of the animals' flanks for $30 \mathrm{~s}$ (Machado et al., 2020).

Body temperature was obtained by thermal imaging from a thermographic camera (TiS10, Fluke, 4,800 pixels resolution), by adjusting the environmental temperature at the time of image recording, and emissivity of biological tissues $\varepsilon=0.98$ (Machado et al., 2021b). Thermal images were obtained with a fixed distance of $0.50 \mathrm{~m}$ between the animal and the observer (Soerensen et al., 2014), analyzed by SmartView 4.3 software. All thermal images were analyzed in the SmartView 4.3 software.

Lactate was determined by the portable analyzer Lactate Scout 4, EKF Diagnostic GmbH, according to Rocha et al. (2015). Blood samples in the marginal vein of the pig's ear were collected by a veterinarian using a retractable needle $(25 \mathrm{G} \times 16 \mathrm{~mm})$. This procedure was followed by hemostasis, to avoid any type of sequelae. Then, a drop of blood was used on a sample strip (two replicates per animal) and inserted into the portable analyzer, obtaining the results after $15 \mathrm{~s}$.

Salivary cortisol was determined using the Elisa Salimetrics kit, NeogenCorp. Lexington, KY, USA, as described by Dalla Costa et al. (2009). Initially, saliva was collected with the aid of a plastic swab with sterile stuart medium and inserted into an Eppendorf tube. The samples were stored in a freezer at a temperature of $-20^{\circ} \mathrm{C}$ for about 50 min until analysis in a private laboratory.

\section{Statistical Analysis}

The physiological variables were analyzed as a repeated measure over time by the SAS MIXED procedure (SAS Institute Inc. 2012), according to the statistical model: $\mathrm{Y}=\mu+\mathrm{B}_{\mathrm{i}}+\mathrm{C}_{\mathrm{j}}+\mathrm{e}_{\mathrm{ij}}+\mathrm{T}_{\mathrm{k}}+\mathrm{C}_{\mathrm{j}} \mathrm{T}_{\mathrm{k}}+\mathrm{e}_{\mathrm{ijk}}$, where: $\mu=$ overall average; $B_{i}=$ random effect of the block; $C_{j}=$ fixed effect of the trailer compartment; $\mathrm{e}_{\mathrm{ij}}=$ random error; $\mathrm{T}_{\mathrm{k}}=$ fixed effect of time; $\mathrm{C}_{\mathrm{i}} \mathrm{T}_{\mathrm{k}}=$ fixed effect of trailer compartment interaction $\mathrm{x}$ time and $\mathrm{e}_{\mathrm{ijk}}=$ random error at the time level. The means were compared using the Tukey test $(\mathrm{P}<0.05)$.

The ventilation and enthalpy were explored with geostatistics and computational fluid dynamics (CFD). The mean values of the physiological variables of the pigs transported in the upper deck (UD) and lower deck (LD) compartments of the trailer were submitted to ANOVA and compared by the $\mathrm{F}$ test $(\mathrm{P}<0.05)$.

A canonical discriminating multivariate analysis was performed using the SAS CANDISC procedure, to understand the degree of multivariate similarity between the body compartments, associated with the graphical representation that showed the $95 \%$ confidence ellipses of the average treatment vectors was elaborated using Rbio (Bhering, 2017).

\section{RESULTS AND DISCUSSION}

The most favorable environmental conditions for pigs occurred in the compartments in the rear region of the load. There is a greater amount of heat in the compartments located in the frontal region of the load, especially on the lower deck, Figure 2. This behavior can be seen more clearly in Figure 2C, where a large amount of heat is noted in the front load region, with enthalpy values between 86.50 and $89.50 \mathrm{~kJ} / \mathrm{kg}$ of dry air. 


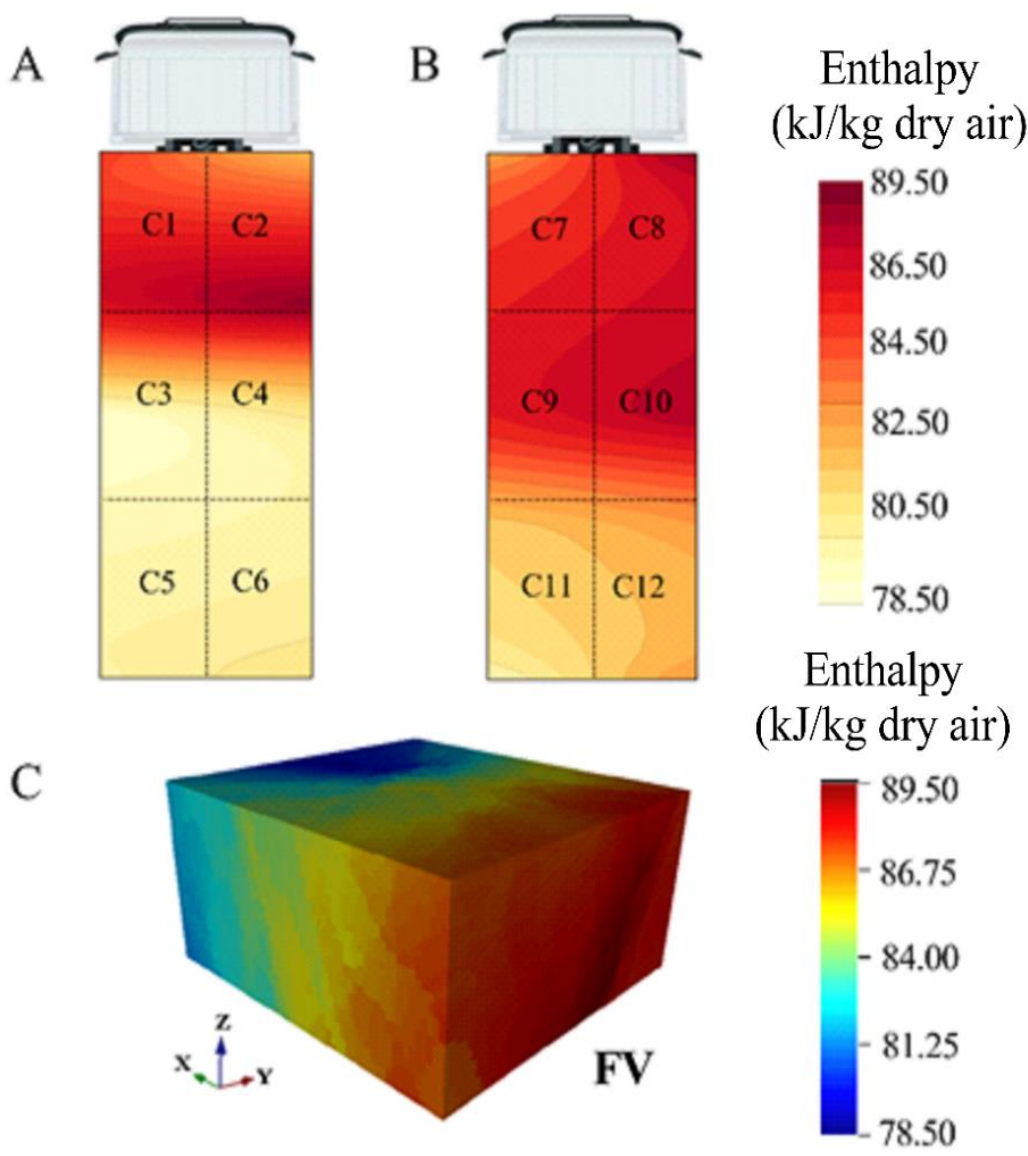

FIGURE 2. Representation of 2D maps of the estimated enthalpy on the upper (A) and lower (B) deck of the trailer, and of the $3 \mathrm{D}$ map of the estimated enthalpy of the load during pig's transport (C). FV = Front of Vehicle.

Enthalpy values between 89.50 and $86.50 \mathrm{~kJ} / \mathrm{kg}$ of dry air (thermal core), provide favorable conditions for the occurrence of thermal stress in pigs, enthalpy> $80 \mathrm{~kJ} / \mathrm{kg}$ of dry air (Silva-Miranda et al., 2012). However, it is noted that the intensity of enthalpy along the trailer is substantially reduced $(\sim 11 \pm 1.2 \mathrm{~kJ} / \mathrm{kg}$ of dry air $)$ in the front-rear direction (Figure 2C).

This thermal profile can be explained by the ventilation pattern, which occurs in reverse (Figure 3).
Thus, the intensity and location of the heat zones are related to the dynamics of ventilation inside the load during transport. In this study, through the simulation of the data, a reduction in the speed of the wind flow $(\sim 32 \%)$ in the region of the truck cabin was observed (Figure 3A), with subsequent directing of the air to the top of the load and to the region rear of the vehicle, thus indicating that there is greater ventilation on the upper deck, especially in the rear area of the load (Figure 3B). 


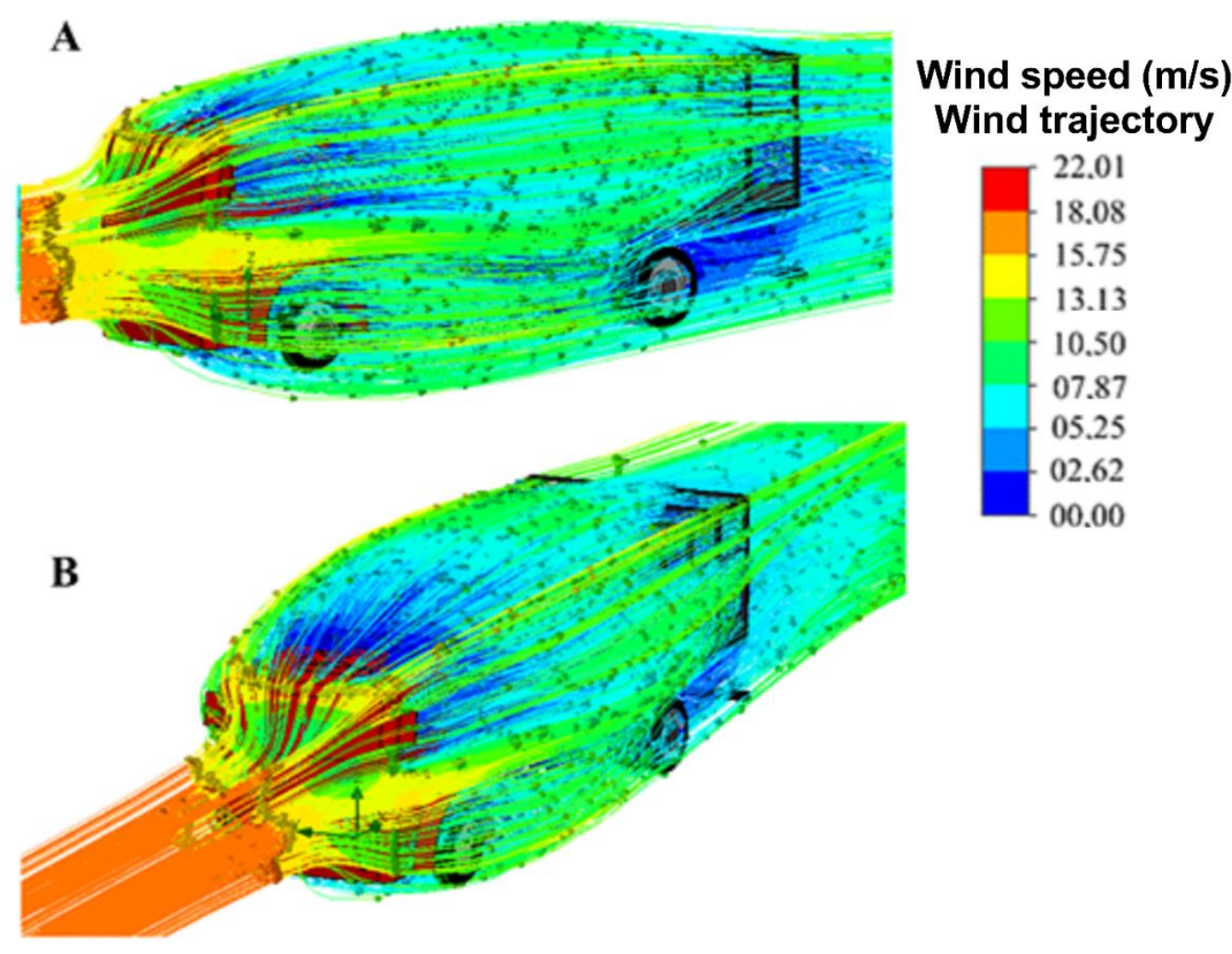

FIGURE 3. Simulation of wind flow along the load during pig transport based on the boundary conditions established in Table 1.

Pigs transported on the upper deck (UD) of the trailer showed higher body temperature averages $(\mathrm{P}=0.022)$ and blood lactate concentration $(\mathrm{P}<0.001)$ compared to those transported on the lower deck (LD). In turn, the pigs transported in the LD of the trailer presented higher values of rectal temperature $(\mathrm{P}<0.001)$ and higher respiratory rate $(\mathrm{P}<0.004)$, as well as higher concentrations of salivary cortisol $(\mathrm{P}=0.001)$, as shown in the Table 2 .

TABLE 2. Means ( \pm SE) of body temperature $(B T)$, rectal temperature $(\mathrm{RT})$, respiratory rate $(\mathrm{RR})$, salivary cortisol and lactate concentration in pig's transport compartments.

\begin{tabular}{|c|c|c|c|c|c|}
\hline Compartments & $\begin{array}{l}\text { BT } \\
\left({ }^{\circ} \mathrm{C}\right) \\
\end{array}$ & $\begin{array}{l}\mathrm{RT} \\
\left({ }^{\circ} \mathrm{C}\right) \\
\end{array}$ & $\begin{array}{c}\mathrm{RR} \\
\text { (breaths / } \mathrm{min} \text { ) } \\
\end{array}$ & $\begin{array}{l}\text { Cortisol } \\
(\mathrm{ng} / \mathrm{mL})\end{array}$ & $\begin{array}{c}\text { Lactate } \\
(\mathrm{mg} / \mathrm{dL})\end{array}$ \\
\hline \multicolumn{6}{|c|}{ Upper Deck (UD) of trailer } \\
\hline $\mathrm{C} 1$ & $38.83 \pm 0.36^{\mathrm{abc}}$ & $39.09 \pm 0.42^{\mathrm{ab}}$ & $90.00 \pm 1.20^{\mathrm{cd}}$ & $33.33 \pm 0.79^{b}$ & $63.81 \pm 1.20^{\mathrm{a}}$ \\
\hline $\mathrm{C} 2$ & $39.04 \pm 0.31^{\mathrm{abc}}$ & $38.91 \pm 0.36^{\mathrm{ab}}$ & $93.00 \pm 0.90^{\mathrm{bc}}$ & $35.06 \pm 0.60^{\mathrm{ab}}$ & $64.04 \pm 0.87^{\mathrm{a}}$ \\
\hline $\mathrm{C} 3$ & $39.94 \pm 0.25^{\mathrm{a}}$ & $38.74 \pm 0.40^{\mathrm{ab}}$ & $92.00 \pm 1.10^{\mathrm{bcd}}$ & $32.62 \pm 0.52^{\mathrm{b}}$ & $62.26 \pm 1.10^{\mathrm{abc}}$ \\
\hline $\mathrm{C} 4$ & $39.90 \pm 0.12^{\mathrm{a}}$ & $38.07 \pm 0.60^{\mathrm{b}}$ & $92.00 \pm 1.00^{\mathrm{bcd}}$ & $32.27 \pm 0.39^{\mathrm{b}}$ & $61.28 \pm 0.68^{\mathrm{abc}}$ \\
\hline C5 & $38.62 \pm 0.10^{\mathrm{abc}}$ & $39.09 \pm 0.42^{\mathrm{ab}}$ & $84.00 \pm 1.30^{\mathrm{e}}$ & $35.65 \pm 0.36^{\mathrm{ab}}$ & $60.04 \pm 1.16^{\mathrm{abc}}$ \\
\hline C6 & $38.18 \pm 0.26^{\mathrm{bc}}$ & $39.59 \pm 0.39^{\mathrm{ab}}$ & $86.00 \pm 2.00^{\mathrm{de}}$ & $34.10 \pm 0.65^{\mathrm{b}}$ & $58.36 \pm 1.63^{\mathrm{bc}}$ \\
\hline \multicolumn{6}{|c|}{ Lower Deck $(L D)$ of trailer } \\
\hline $\mathrm{C} 7$ & $38.77 \pm 0.40^{\mathrm{abc}}$ & $40.57 \pm 0.56^{a}$ & $100.00 \pm 1.50^{\mathrm{a}}$ & $37.70 \pm 0.80^{\mathrm{a}}$ & $59.28 \pm 0.78^{\mathrm{abc}}$ \\
\hline $\mathrm{C} 8$ & $38.93 \pm 0.42^{\mathrm{abc}}$ & $40.48 \pm 0.54^{\mathrm{a}}$ & $102.00 \pm 1.20^{\mathrm{a}}$ & $37.76 \pm 0.88^{\mathrm{a}}$ & $59.43 \pm 0.86^{\mathrm{abc}}$ \\
\hline C9 & $37.80 \pm 0.29^{\mathrm{bc}}$ & $39.97 \pm 0.55^{\mathrm{ab}}$ & $89.00 \pm 1.00^{\text {cde }}$ & $33.52 \pm 0.68^{b}$ & $57.23 \pm 1.06^{\mathrm{c}}$ \\
\hline $\mathrm{C} 10$ & $37.98 \pm 0.31^{\mathrm{bc}}$ & $39.83 \pm 0.38^{\mathrm{ab}}$ & $96.00 \pm 1.40^{\mathrm{b}}$ & $33.44 \pm 0.84^{\mathrm{b}}$ & $58.53 \pm 1.10^{\mathrm{bc}}$ \\
\hline $\mathrm{C} 11$ & $37.54 \pm 0.28^{c}$ & $38.63 \pm 0.47^{\mathrm{ab}}$ & $90.00 \pm 1.50^{\mathrm{cd}}$ & $33.24 \pm 1.12^{\mathrm{b}}$ & $57.84 \pm 0.96^{\mathrm{bc}}$ \\
\hline $\mathrm{C} 12$ & $37.85 \pm 0.30^{\mathrm{bc}}$ & $38.83 \pm 0.35^{\mathrm{ab}}$ & $88.00 \pm 1.20^{\text {cde }}$ & $33.87 \pm 1.20^{\mathrm{b}}$ & $57.26 \pm 0.80^{c}$ \\
\hline $\mathrm{CV}(\%)$ & 3.66 & 4.97 & 9.06 & 8.79 & 7.45 \\
\hline $\mathrm{P}$ value & 0.022 & $<0.001$ & 0.004 & 0.001 & $<0.001$ \\
\hline Mean UD & $38.98 \pm 0.23^{\mathrm{A}}$ & $38.92 \pm 0.43^{\mathrm{B}}$ & $90.00 \pm 1.25^{\mathrm{B}}$ & $33.84 \pm 0.55^{\mathrm{B}}$ & $61.63 \pm 1.10^{\mathrm{A}}$ \\
\hline Mean LD & $38.15 \pm 0.33^{\mathrm{B}}$ & $39.72 \pm 0.47^{\mathrm{A}}$ & $94.00 \pm 1.30^{\mathrm{A}}$ & $34.92 \pm 0.92^{\mathrm{A}}$ & $58.26 \pm 0.92^{\mathrm{B}}$ \\
\hline
\end{tabular}

The means followed by the same lower-case letters (trailer deck) (trailer compartments) in the same column do not differ according to the $\mathrm{F}$ and Tukey tests, respectively $(\mathrm{P}<0.05)$. CV = coefficient of variation. 
In the frontal region $(\mathrm{C} 1$ and $\mathrm{C} 2)$ of the $\mathrm{UD}$, the highest $(\mathrm{P}<0.05)$ averages of lactate occurred in pigs. In addition, the animals transported in compartments $\mathrm{C} 7$ and $\mathrm{C} 8$ of LD had the highest $(\mathrm{P}<0.05)$ mean values of salivary cortisol and respiratory rate, when compared to the other compartments of LD (Table 2).

The increase in cortisol levels is related to the increase in characteristic adrenocortical activity, linked to the activation of the autonomic nervous system caused by stress (Rocha et al., 2019). Additionally, an increase in respiratory rate suggests a greater demand for physiological mechanisms to maintain the temperature of the body nucleus (Zhao et al., 2016; Sommavilla et al., 2017; Rocha et al., 2019).

This effect was seen in pigs transported in the LD compartments of the trailer, especially in C7 and C8 (Table 2 ), indicating a response to the deleterious effects of heat stress on pigs located in these areas. This occurred due to the formation of the thermal heat core (Figure 2) by the development of a vacuum (negative pressure gauge) in the area in question (Kettlewell et al., 2001), thus resulting in a reduced rate of heat removal in this region of the load (Figure 3).

The results of the present study indicate that the location of the animal in the load during transport has an impact on its well-being, because some compartments inside the body are subject to higher temperatures (heat) (Figure 2). Brown et al., (2011) reported higher temperatures in the front compartments during winter (+ $\left.10.3^{\circ} \mathrm{C}\right)$ and summer $\left(+2.1^{\circ} \mathrm{C}\right)$ in a pot-belly body, while the upper compartments showed lower temperatures and lower risk associated with heat stress in pig transport.

This concern is not restricted to pigs, a series of studies have shown a heterogeneous temperature and relative humidity in the load during the transport of broilers, with the greatest risk observed in birds transported in the center of the load, where heat dissipation is more difficult (Kettlewell et al., 1993; Mitchell \& Kettlewell, 1998; Barbosa-Filho et al., 2009). Similarly, the presence of a "thermal core" in the frontal region of the load was verified in this study, with the potential to reduce the heat dissipation of pigs (Figure 2C).

The UD compartments of the trailer have more favorable ventilation conditions for pigs during transport (Figure 3). However, the results indicate that pigs are more susceptible to physical stress related to direct exposure to solar radiation during transport (trailer without cover), the greater effort during boarding, due to the steeper ramps $\left(58^{\circ}\right)$ compared to the $\operatorname{LD}\left(30^{\circ}\right)$ and the greater vibration of the bodywork during the journey (Peeters et al., 2008).

This scenario may have caused muscle exhaustion and increased demand for oxygen and, thus, anaerobic glycolysis, generating an increase in the serum lactate concentration of pigs transported in UD (Table 2) (RoldanSantiago et al., 2013; Mota-Rojas et al., 2014). The increase in swine blood lactate is usually related to muscle exhaustion (Mota-Rojas et al., 2012; Roldan-Santiago et al., 2013; Martínez-Rodríguez et al., 2015).

Conte et al. (2015) showed that in pot-belly bodies, the compartments located in the upper front and lower rear regions provided greater physical effort to the pigs due to boarding with steeper internal ramps (up to $32^{\circ}$ ). The authors reported an increase in the temperature of the gastrointestinal tract of swine after loading and during transport, compared to animals transported in other compartments of the trailer.

Table 3 shows the standardized canonical coefficients of the total sample and the total variation explained by each canonical variable. The first canonical variable (Can 1), or Fisher's linear discriminant function, explained $63.04 \%$ of the total variation of the trailer compartments, which can be considered reasonable and Can 2 explained $15.90 \%$ of the total variation. Greater weighting of enthalpy, relative humidity, rectal temperature and salivary cortisol was observed in the Can 1 extraction process, as well as greater weighting of surface temperature and blood lactate for Can 2 extractions, suggesting a variation related to thermal stress by heat (Can 1) and physical stress (Can 2).

TABLE 3. Standardized canonical coefficients for total sample and total variation explained by each canonical variable (Can).

\begin{tabular}{|c|c|c|}
\hline \multirow{2}{*}{ Variables } & \multicolumn{2}{|c|}{ Canonical Variables } \\
\hline & Can1 & Can2 \\
\hline Air Temperature & 0.58 & 0.05 \\
\hline Relative Humidity & $-1.54^{*}$ & -0.08 \\
\hline Enthalpy & $-3.45^{*}$ & 0.13 \\
\hline Body Temperature & -0.07 & $71.08 *$ \\
\hline Rectal Temperature & $-15.30 *$ & 0.57 \\
\hline respiratory rate & -0.50 & -0.01 \\
\hline Salivary Cortisol & $-84.09 *$ & 0.07 \\
\hline Lactate & 0.41 & $103.57^{*}$ \\
\hline Variation $(\%)$ & 63.04 & 15.90 \\
\hline Accumulated Variation (\%) & 63.04 & 78.94 \\
\hline
\end{tabular}

* Scores with high weighting in the construction of Can> 1.0 
In a multivariate perspective, the results confirm the hypothesis attributed to explain the physiological parameters of the pigs monitored (Table 2). The discriminant analysis allowed a clear discrimination between the UD and LD cargo deck, the UD compartments were moved to quadrant II by the Can 2 axis in the positive direction, being overlapped by the mean vectors of body temperature and lactate (Figure 4).

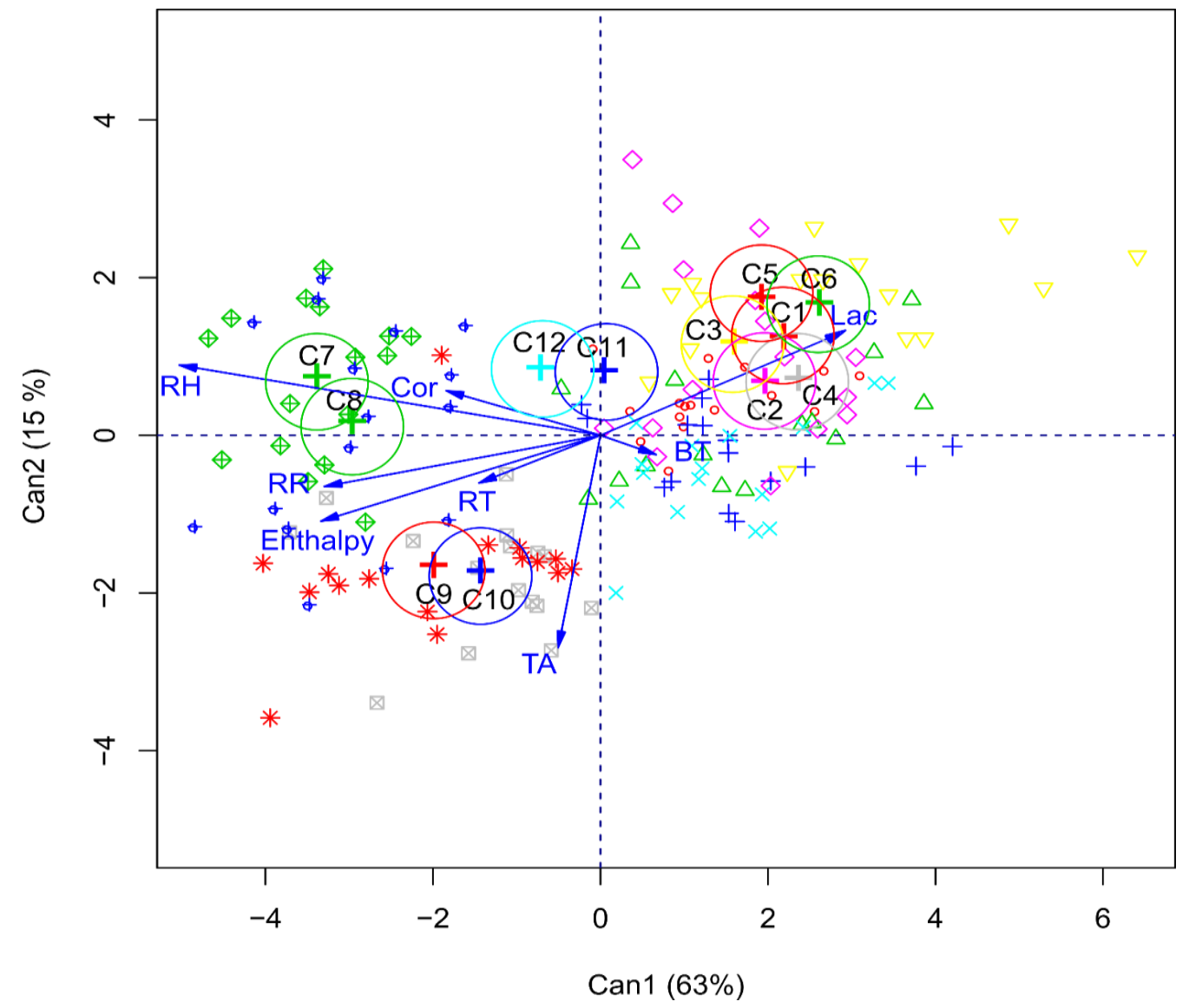

FIGURE 4. Dissimilarity between load compartments by Can 1 x Can2. TA = air temperature; $\mathrm{RH}=$ relative humidity of the air; $\mathrm{BT}=$ body temperature; $\mathrm{RT}=$ rectal temperature; $\mathrm{RR}=$ respiratory rate; Cor $=$ salivary cortisol and Lac $=$ blood lactate. The symbol and color vary to make it easier to identify the repetitions in each treatment.

On the other hand, the LD compartments were displaced to quadrants I and III by the Can 1 axis in the negative direction, being superimposed by the mean vectors of the heat stress indicators (for example: cortisol, rectal temperature and enthalpy), except for the compartments C11 and C12 of the LD that remained close to the centroid, showing a pattern of moderate balance between Can 1 and Can2 (Figure 4).

It is important to note that the most harmful space of the truck cargo to the well-being of the animals is located in the frontal region of the LD (C7 and C8). However, the results presented occur due to the additive effect of stress (physiological and physical) caused by heat stress, but also by the vibration of the load (Peeters et al., 2008), by the handling of loading / unloading (Brown et al., 2005; Goumon \& Faucitano, 2017) and in the order of loading (Conte et al., 2015; Goumon \& Faucitano, 2017; Machado et al., 2021a).

The management and mixing of lots can also have a detrimental impact on well-being (Ison et al., 2018) and can be identified in blood parameters, although the reliability of some parameters is questionable, given the context and the sampling capacity within an appropriate window after "treatment" (Carreras et al., 2017).
Therefore, the average physiological indicators recorded in pigs transported in these areas of the load can be confused with the effects of handling, vibration and loading order. However, as all pre- and post-transport practices were identical, there is a genuine effect related to the heat zones in the cargo and the thermal stress caused to the animals among the pigs arranged in the compartments and location of the trailer deck.

The practice of "wetting the load" during loading, common in tropical regions, may have contributed negatively to the efficiency of heat dissipation of pigs during transport, it is known that wetting can provide the accumulation of water in the trailer (Pinheiro et al., 2020), expanding the water vapor content in the air parcel close to the animals, especially in the frontal (C7 and C8) and central (C9 and C10) regions of the $\mathrm{LD}$, due to the deficiency of ventilation in these areas.

This scenario, in addition to reducing the thermoregulation capacity of pigs, since heat dissipation through panting becomes inefficient (Nardone et al., 2010), can cause a high energy cost and result in excessive $\mathrm{CO}_{2}$ loss (Mota-Rojas et al., 2012), causing a drop in partial pressure and in the concentration of carbonic acid and hydrogen, which can increase the DOA rate (Tasse \& Molento, 2019), dehydration (Machado et al., 2016) and time post-transport recovery of animals (Johnson et al., 2018). 


\section{CONCLUSIONS}

During transport, heat zones of different magnitudes were observed in cargo compartments. It was found that pigs transported in compartments located on the lower deck of the trailer are more susceptible to heat stress due to the dynamics of ventilation. Pigs transported in compartments on the upper deck are more susceptible to physical stress and muscle exhaustion due to possibly by the solar exposure and vibrations do trailer.

\section{ACKNOWLEDGMENTS}

We appreciate the support of the Coordination for the Improvement of Higher Education Personnel (CAPES).

\section{REFERENCES}

Averós X, Knowles TG, Brown SN, Warriss PD, Gosálvez LF (2010) Factors affecting the mortality of weaned piglets during commercial transport between farms. Veterinary Record 167: 815-819. DOI: https://doi.org/10.1136/vr.c6226

Barbosa-Filho JAD, Vieira FMC, Silva IJO, Garcia DB, Silva MAN, Fonseca BHF (2009) Poultry transport: microclimate characterization of the truck during the winter. Revista Brasileira de Zootecnia 3598: 2442-2446. DOI: https://doi.org/https://doi.org/10.1590/S151635982009001200021.

Bhering LL (2017) Rbio: A tool for biometric and statistical analysis using the R platform. Crop Breeding and Applied Biotechnology 17:187-190. DOI: https://doi.org/1010.1590/1984-70332017v17n2s29

Bligh J (1985) Temperature regulation in mammals and other vertebrates. Boca Raton, CRC Press, p75-96.

Brown JA, Samarakone S, Crowe T, Bergeron TR, Widowski T, Correa JA, Faucitano L, Torrey S, Gonyou HW (2011) Temperature and humidity conditions in trucks transporting pigs in two seasons in eastern and western Canada. T ASABE 54: 2311-2318. DOI: https://doi.org/10.13031/2013.40650

Brown SN, Knowles TG, Wilkins SA, Chadd, PD, Warriss PD (2005) The response of pigs to being loaded or unloaded onto commercial animal transported using three systems. The Veterinary Journal 170:91-100. DOI: https://doi.org/10.1016/j.tvj1.2004.05.003

Carreras R, Arroyo L, Mainau E, Valent D, Bassols A, Dalmau A, Faucitano L, Manteca X, Velarde A (2017) Can the way pigs are handled alter behavioural and physiological measures of affective state?. Behavioural Processes 142: 9198. DOI: https://doi.org/10.1016/j.beproc.2017.06.005

Conte S, Faucitano L, Bergeron R, Torrey S, Gonyou HW, Crowe T, Toth Tamminga E, Widowski TM (2015) Effects of season, truck type, and location within truck on gastrointestinal tract temperature of market-weight pigs during transport Journal of Animal Science 93:5840-5848. DOI: https://doi.org/10.2527/jas.2015-9338
Correa JA, Gonyou HW, Torrey S, Widowski T, Bergeron R, Crowe TG, Laforest JP, Faucitano L (2013) Welfare and carcass and meat quality of pigs being transported for two hours using two vehicle types during two seasons of the year Canadian Journal of Animal Science 93:43-55. DOI: https://doi.org/10.4141/CJAS2012-088

Dalla Costa OA, Ludke JV, Coldbelle A, Kich JD, Costa MJRP, Faucitano L. Peloso JV, Roza DD (2009) Efeito do manejo pré-abate sobre alguns parâmetros fisiológicos em fêmeas suínas pesadas. Ciência Rural 39:852-858. DOI: http://dx.doi.org/10.1590/S0103-84782009000300033

Dos Reis JGM, Machado ST, Santos R, Nääs IA, Oliveira RV (2015) Financial losses in pork supply chain: a study of the pre-slaughter handling impacts. Engenharia Agrícola 35: 163-170. DOI: http://dx.doi.org/10.1590/1809-4430Eng.Agric.v35n1p163-170/2015

Faucitano L (2018) Preslaughter handling practices and their effects on animal welfare and pork quality. Journal of Animal Science 96:728-738. DOI:

https://doi.org/10.1093/jas/skx064

Fox J, Widowski T, Torrey S, Nannoni E, Bergeron R, Gonyou HW, Brown JA, Crowe T, Mainau E, Faucitano L (2014) Water sprinkling market pigs in a stationary trailer. 1. Effects on pig behaviour, gastrointestinal tract temperature and trailer micro-climate. Livestock Science 160:113-123. DOI: https://doi.org/10.1016/j.livsci.2013.12.019

Gasparin E, Souza EG, Uribe-Opazo, MA, Santos RN, Bier VA, Rocha DM (2017) 3D thematic maps of the chemical parameters of orange fruits. Acta ScientiarumTechnology 39:417-423. DOI:

https://doi.org/10.4025/actascitechnol.v39i4.29575

Goumon S, Faucitano L (2017) Influence of loading handling and facilities on the subsequent response to preslaughter stress in pigs. Livestook Science 200:6-13. DOI: https://doi.org/10.1016/j.livsci.2017.03.021

Ison SH, Bates RO, Ernst CW, Steibel JP, Siegford JM (2018) Housing, ease of handling and minimising inter-pig aggression at mixing for nursery to finishing pigs as reported in a survey of North American pork producers. Applied Animal Behaviour Science 205:159-166. DOI: https://doi.org/10.2527/1998.7682080x

Johnson JS, Aardsma MA, Duttlinger AW, Kpodo KR (2018) Early life thermal stress: Impact on future thermotolerance, stress response, behavior, and intestinal morphology in piglets exposed to a heat stress challenge during simulated transport. Journal of Animal Science 96:1640-1653. DOI: https://doi.org/10.1093/jas/sky107

Kettlewell P, Mitchell, M, Meehan A (1993) Distribution of thermal loads within poultry transport vehicles. Agricultural Engineer 48:26-30. Available: https://agris.fao.org/agrissearch/search.do?recordID=US201301777149

Kettlewell PJ, Hoxey RP, Hampson CJ, Green NR, Veale BM, Mitchell MA (2001) Design and Operation of a Prototype Mechanical Ventilation System for Livestock Transport Vehicles 79:429-439. DOI: https://doi.org/10.1006/jaer.2001.0713 
Machado NAF, Martin JE, Barbosa-Filho JAD, Dias CTS, Pinheiro DG, De Oliveira KPL, Souza-Junior JBF (2021a). Identification of trailer heat zones and associated heat stress in weaner pigs transported by road in tropical climates. Journal of Thermal Biology 97: 102882. DOI: https://doi.org/10.1016/j.jtherbio.2021.102882

Machado NAF, Da Costa LBS, Barbosa-Filho JAD, De Oliveira KPL, De Sampaio LC, Peixoto MSM, Damasceno FA (2021b) Using infrared thermography to detect subclinical mastitis in dairy cows in compost barn systems. Journal of Thermal Biology 97:102881. DOI: https://doi.org/10.1016/j.jtherbio.2021.102881

Machado NAF, Parente MOM, Parente HN, Zanine AM, Moreira-Filho MA, Cunha ICL, Sousa JMS, Anjos LF, Ferreira DJ, Araújo JS (2020) The physiological response, feeding behaviour and water intake of feedlot lambs supplemented with babassu oil or buriti oil. Biological Rhthm Research 51:213-224. DOI: https://doi.org/10.1080/09291016.2018.1526499

Machado ST, Nääs IA, Neto MM, Vendrametto O, Dos Reis JGM (2016). Effect of transportation distance on weight losses in pigs from dehydration. Engenharia Agrícola 36:1229-1238. DOI: https://doi.org/10.1590/1809-4430Eng.Agric.v36n6p1229-1238/2016

Martínez-Rodríguez R, Roldan-Santiago P, OrozcoGregorio H, Trujillo-Ortega M, Mora-Medina P, González-Lozano M, Sánchez-Hernández M, BonillaJaime H, García-Herrera R, Hernández-Trujillo E, MotaRojas D (2015) Physiological responses and blood gas exchange following long-distance transport of piglets weaned at different ages over unpaved or paved roads. Livestock Science 172: 69-78. DOI:

https://doi.org/10.1016/j.livsci.2014.12.013

Mitchell MA, Kettlewell PJ (1998) Physiological stress and welfare of broiler chickens in transit: +solutions not problems! Poultry Science Journal 77:1803-1814. DOI: https://doi.org/10.1093/ps/77.12.1803

Mota-Rojas D, Becerril-Herrera M, Roldan-Santiago P, Alonso-Spilsbury M, Flores-Peinado S, RamírezNecoechea R, Ramírez-Telles JA, Mora-Medina P, Pérez M, Molina E, Soní E, Trujillo-Ortega ME (2012) Effects of long-distance transportation and $\mathrm{Co}_{2}$ stunning on critical blood values in pigs. Meat Science 90:893-898. DOI: https://doi.org/10.1016/j.meatsci.2011.11.027

Mota-Rojas D, Santiago-Roldán P, Pedraza EP, Rodríguez RM, Hernández-Trujillo L, Ortgea MET (2014) Stress factors in weaned piglet. Vetérinaria Mexico 45:37-51. Available:

http://www.scielo.org.mx/scielo.php?script=sci_arttext\&pi $\mathrm{d}=\mathrm{S} 0301-50922014000200005 \& \operatorname{lng}=\mathrm{es} \& \mathrm{nrm}=\mathrm{iso}$

Nardone A, Ronchi B, Lacetera N, Ranieri MS, Bernabucci U (2010) Effects of climate changes on animal production and sustainability of livestock systems.

Livestock Science 130:57-69. DOI:

https://doi.org/10.1016/j.livsci.2010.02.011
Peeters E, Deprez K, Beckers F, De Baerdemaeker J, Aubert AE, Geers R (2008) Effect of driver and driving style on the stress responses of pigs during a short journey by trailer. Animal Welfare 17:189-196. Available:

http://citeseerx.ist.psu.edu/viewdoc/download?doi=10.1.1. 657.7892\&rep=rep1\&type $=$ pdf

Pereira TL, Titto EAL, Conte S, Devillers N, Sommavilla R, Diesel T, Dalla Costa FA, Guay F, Friendship R, Crowe T, Faucitano L (2018) Application of a ventilation fanmisting bank on pigs kept in a stationary trailer before unloading: Effects on trailer microclimate, and pig behaviour and physiological response. Livestock Science 216:67-74. DOI:

https://doi.org/10.1016/j.livsci.2018.07.013

Pinheiro DG, Barbosa-Filho JAD, Machado NAF (2020)

Effect of wetting method on the broiler transport in Brazilian Northeast. Journal of Animal Behaviour and Biometeorology 8, 168-173. DOI: https://doi.org/10.31893/jabb.20022

Pinheiro DG, Machado NAF, Barbosa Filho JAD, Silva IJO (2021) Computational Analysis of Load Ventilation in Broiler Transport. Engenharia Agrícola 41: 9-18. DOI: https://doi.org/10.1590/1809-4430-eng.agric.v41n1p9$18 / 2021$

Remy N, Boucher A, Wu J (2009) Applied geostatistics with SGeMS: a user's guSCI. Cambridge, Cambridge University Press.

Rioja-Lang FC, Brown JA, Brockhoff EJ, Faucitano L (2019) A review of swine transportation research on priority welfare issues: A canadian perspective. Frontiers in Veterinary Science 6:1-12. DOI: https://doi.org/10.3389/fvets.2019.00036

Rocha LM, Devillers N, Maldague X, Kabemba FZ, Fleuret J, Guay F, Faucitano L (2019) Validation of Anatomical Sites for the Measurement of Infrared Body Surface Temperature Variation in Response to Handling and Transport. Animals 9:425. DOI: https://doi.org/10.3390/ani9070425

Rocha LM, Dionne A, Saucier L, Nannoni E, Faucitano L (2015) Hand-held lactate analyzer as a tool for the realtime measurement of physical fatigue before slaughter and pork quality prediction. Animal 24: 707-714. DOI: https://doi.org/10.1017/S1751731114002766

Rodrigues VC, da Silva I, Vieira F, Nascimento S (2011) A correct enthalpy relationship as thermal comfort index for livestock. International Journal of Biometeorology 55: 455-459. DOI: https://doi.org/10.1007/s00484-010-0344-y

Roldan-Santiago P, Martinez-Rodriguez R, Yanez-Pizana A, Trujillo-Ortega ME, Sanchez-Hernandez M, PerezPedraza E, Mota-Rojas D (2013) Stressor factors in the transport of weaned piglets: A review. Veterinární medicína 58:241-251. DOI: https://doi.org/10.17221/6805-VETMED 
SAS. 2012. SAS/STAT® 9.3 User's guide. Cary, SAS Institute.

SGeMS - Stanford Geostatistical Modeling Software (2010) General introduction mentioned there seems to be a new version, p20. Available:

http://sgems.sourceforge.net/?q=node/121

Silva-Miranda KO, Borges G, Menegale VLC, Silva IJO (2012) Effects of environmental conditions on sound level emitted by piglets. Engenharia Agrícola 32:435-455. DOI: http://dx.doi.org/10.1590/S0100-69162012000300003

Soerensen DD, Clausen S, Mercer JB, Pedersen LJ (2014)

Determining the emissivity of pig skin for accurate infrared thermography. Computers and Electronics in Agriculture 109:52-58. DOI:

https://doi.org/10.1016/j.compag.2014.09.003
Sommavilla R, Faucitano L, Gonyou H, Seddon Y, Bergeron R, Widowski T, Crowe T, Connor L, Scheeren MB, Goumon S, Brown J (2017) Season, transport duration and trailer compartment effects on blood stress indicators in pigs: Relationship to environmental, behavioral and other physiological factors, and pork quality traits. Animals 7:1-12. DOI: https://doi.org/10.3390/ani7020008

Tasse ME, Molento CFM (2019) Injury and condemnation data of pigs at slaughterhouses with federal inspection in the state of Paraná, Brazil, as indicators of welfare during transportation. Ciência Rural 49:1-8. DOI: https://doi.org/10.1590/0103-8478cr20180243

Zhao Y, Xin H, Harmon JD, Bass TJ (2016) Mortality rate of weaned and feeder pigs as affected by ground transportation conditions. Transactions - American Society of Agricultural Engineers. 59:943-948. DOI: https://doi.org/10.13031/trans.59.11671 